the larvæ are very free from parasites, which in my opinion tells somewhat against that view.

Salisbury, March 6-10, 1898.-Of four larvæ of $L$. chrysippus I have taken this season two were killed by a parasitic fly [probably a Tachina] which attacks many different butterfly larvæ.

In his "Rhopalocera Malayana" (p. 407) Mr. Distant writes: "Mr. W. F. Kirby has kindly drawn my attention to the fact that several species of Chalcis have been reared from East Indian Danaids." *

[Colonel J. W. Yerbury at Aden "lost a great number of chrysippus larvæ from the attacks of a large dipterous parasite, one of the Tachinine" (Journ. Bomb. Nat. Hist. Soc., 1892, p. 209).

Professor Félix Plateau, in his interesting paper on Abraxas grossulariata, L. (Mém. de la Soc. Zool. de France, tome vii, 1894 , p. 375), also referred to on pp. 325-7, states that he found twenty-two caterpillars out of fifty-one, 43 per cent., attacked by insect parasites, viz. of Hymenoptera, two species of Microgaster and one of Ichneumon; of Diptera, the Tachinid Exorista vulgaris (Fallen). The caterpillar, pace Professor Plateau, is most conspicuous, and, as the Professor admits in the above-quoted paper, is refused by European insect-eating, vertebrates with wonderful unanimity.

In the autumn of 1888 I found the conspicuous gregarious larvæ of Pieris brassicæ suffered to an enormous extent from the attacks of Ichneumonidx. No less than 424 mature larvæ out of 631 died from this cause (Trans. Ent. Soc. Lond., 1892, p. 439). I have also observed an excessively high rate of mortality from the same cause among the conspicuous specially-defended larvæ of Porthesia aurifua. Dr. F. A. Dixey informs me that he has found the larvæ of Euchelia jacobrx much infested by ichneumons.E. B. P.]

\title{
8. Experiments on Lizards and Frogs. (G. A. K. M.)
}

[Experiments with lizards and frogs were few and the results negative. A large number of the S. African species are no doubt specialized to eat only certain kinds of food, and these would be useless for experiment if their natural

* The names of Chalcis cuplea, Hope, and C. albicrus, Klug, are specially mentioned. 
prey did not include members of the insect Order which it was desired to test. European lizards freely eat insects of all Orders, and have been found very satisfactory for such experiments. The African species which Mr. Marshall has actually seen hunting butterflies (see p. 435) should afford very valuable testimony as to the relative palatability of various Lepidopterous species and groups. Even if intolerant of captivity, they would probably thrive in an enclosure out of doors, with plenty of air, sun, and space. -E. B. P.]

Estcourt, Oct. 15, 1896.-I have just got a lizard to try experiments on with regard to the edibility of insects, but though it eats Diptera and some Orthoptera readily, it will not look at any of the butterflies I have given it, viz. Terias brigitta, Pontia hellica, and Zeritis tailiosama. I had previously tried an Agama lizard with the same result, as I found that its natural food consisted almost entirely of ants.

Malvern, Feb. 21, 1897.-I have found Pontia hellica to be distasteful to a lizard.

Salisbury, March 6-10, 1898.-I kept a lizard for about a week, but it refused to eat any of the butterflies I gave it, but as it also refused termites the results were unreliable, and I let it go. In experiments of this kind the natural habits of the predatory animal must be taken into account, and the fact that a lizard prefers a fly to a butterfly may in some cases have no greater significance, so far as mimetic problems are concerned, than that a frugivorous bird prefers a berry to a butterfly.

Salisbury, June 5, 1898.-I have made several attempts at experiments with butterflies and lizards, but with no satisfactory results, as the latter seem to be unwilling to eat anything at all in captivity, remaining in a sort of listless condition.

Malvern, May 14, 1897.-Caught three frogs and put them in a box, and put in a wingless specimen of Acræa natalica. After a short interval the largest frog swallowed it. He made no sign to show that it was distasteful, nor did he disgorge it afterwards. For several days I put in specimens of various species, both edible and otherwise, but as none of the frogs paid the slightest attention to them I ceased to experiment. 


\section{$2 \mathrm{BHL}$ Biodiversity Heritage Library}

1902. "8. Experiments on Lizards and Frogs. (G. A. K. M.)." Transactions of the Entomological Society of London 50, 338-339.

https://doi.org/10.1111/j.1365-2311.1902.tb02399.x.

View This Item Online: https://www.biodiversitylibrary.org/item/48243

DOI: https://doi.org/10.1111/j.1365-2311.1902.tb02399.x

Permalink: https://www.biodiversitylibrary.org/partpdf/25250

\section{Holding Institution}

Smithsonian Libraries

\section{Sponsored by}

Smithsonian

\section{Copyright \& Reuse}

Copyright Status: Public domain. The BHL considers that this work is no longer under copyright protection.

This document was created from content at the Biodiversity Heritage Library, the world's largest open access digital library for biodiversity literature and archives. Visit BHL at https://www.biodiversitylibrary.org. 